Swarthmore College

Works

Summer 2011

\title{
The Rubicon Theory Of War: How The Path To Conflict Reaches The Point Of No Return
}

D. D. P. Johnson

Dominic Tierney

Swarthmore College, dtierne1@swarthmore.edu

Follow this and additional works at: https://works.swarthmore.edu/fac-poli-sci

Part of the Political Science Commons

Let us know how access to these works benefits you

\section{Recommended Citation}

D. D. P. Johnson and Dominic Tierney. (2011). "The Rubicon Theory Of War: How The Path To Conflict Reaches The Point Of No Return". International Security. Volume 36, Issue 1. 7-40.

https://works.swarthmore.edu/fac-poli-sci/19

This work is brought to you for free by Swarthmore College Libraries' Works. It has been accepted for inclusion in Political Science Faculty Works by an authorized administrator of Works. For more information, please contact myworks@swarthmore.edu. 


\title{
The Rubicon Theory $\mid$ Dominic D.P. Johnson of War and Dominic Tierney
}

\author{
How the Path to Conflict Reaches the \\ Point of No Return
}

halted his army on the banks of the Rubicon River in northern Italy. According to Suetonius, he paused in momentary hesitation, before sweeping across the waters toward Rome with the immortal phrase Alae iacta est (The die has been cast). ${ }^{1}$ By violating an ancient Roman law forbidding any general to cross the Rubicon with an army, Caesar's decision made war inevitable. Ever since, "crossing the Rubicon" has come to symbolize a point of no return, when the time for deliberation is over and action is at hand.

In this article we set out the Rubicon theory of war. When people believe they have crossed a psychological Rubicon and perceive war to be imminent, they switch from what psychologists call a "deliberative" to an "implemental" mind-set, triggering a number of psychological biases, most notably overconfidence. ${ }^{2}$ These biases can cause an increase in aggressive or risky military planning. Furthermore, if actors believe that war is imminent when it is not in fact certain to occur, the switch to implemental mind-sets can be a causal factor in the outbreak of war, by raising the perceived probability of military victory and encouraging hawkish and provocative policies.

The Rubicon theory of war has several important implications for international relations theory and practice. First, it helps to resolve a major paradox in international relations: the widespread fear and anxiety that underlies the security dilemma in times of peace and the prevalence of overconfidence on the

Dominic D.P. Johnson is Reader in Politics and International Relations at the University of Edinburgh. Dominic Tierney is Assistant Professor of Political Science at Swarthmore College.

The authors would like to thank Peter Gollwitzer, Ellen Langer, Jack Levy, Rose McDermott, Amy Oakes, Stephen Peter Rosen, Shelley Taylor, Bradley Thayer, and Richard Wrangham for comments on work leading to this manuscript. An early version of the paper was presented as "The Tipping Point for War: Overconfidence and the Certainty of Conflict" at the 2007 annual convention of the International Studies Association in Chicago, Illinois, and the authors thank Il Hyun Cho, Tara Lavallee, and Jessica Weeks for their constructive suggestions. Finally, they thank the anonymous reviewers for extremely thorough and helpful comments.

1. C. Suetonius Tranquillus, The Lives of the Twelve Caesars, Vol. 1: Julius Caesar (Cambridge, Mass.: Harvard University Press, 1989).

2. Peter M. Gollwitzer, "Mindset Theory of Action Phases," in Paul A.M. Van Lange, Arie W. Kruglanksi, and E. Tory Higgins, eds., Handbook of Theories of Social Psychology, Vol. 1 (London: Sage, 2011), pp. 526-545. "Mind-set" refers to characteristic cognitive orientations, which represent the sum total of activated cognitive procedures. 
eve of war. ${ }^{3}$ Part of the explanation may be that actors experience a significant switch in mind-set as conflict draws near.

Second, the Rubicon theory advances the debate about whether leaders or states are rational actors in international politics. ${ }^{4}$ If rationality depends on mind-sets, then the accuracy of the rational actor model hinges on when during a crisis one looks for evidence. Early on in the decisionmaking process, a leader is more likely to be in a deliberative mind-set and may approximate a rational actor. Later during the crisis, the same leader is more likely to be in an implemental mind-set, and may display a range of biases that deviate from rationality.

Third, the study contributes to the growing literature on the role of psychology in international relations. Scholars have proposed a wide range of psychological factors as causes of war, including glory, pride, honor, reputation, revenge, justice, fear, and hatred, as well as numerous biases in judgment and decisionmaking. ${ }^{5}$ Here, we focus on the role of shifting mind-sets in military planning and the outbreak of war. Because mind-sets are a master lever that suppresses or amplifies a range of associated psychological biases, the Rubicon theory of war distills what can seem like a laundry list of biases into a coherent, systematic, and testable pattern. Implemental mind-sets cause several different biases to push judgment and decisionmaking in the same direction, promoting overconfidence.

Fourth, the Rubicon theory contributes to a long-standing research program linking overconfidence and war. In two landmark studies a quarter of a century apart, Geoffrey Blainey argued that overconfidence (or "false optimism") is "a potent and pervasive cause of war," and Stephen Van Evera found it "crucial to an understanding of war." ${ }^{\prime 6}$ Overconfidence can lead decisionmakers to

3. Robert Jervis, "Cooperation under the Security Dilemma," World Politics, Vol. 30, No. 2 (January 1978), pp. 167-214; and Geoffrey A. Blainey, The Causes of War (New York: Free Press, 1973).

4. James D. Fearon, "Rationalist Explanations for War," International Organization, Vol. 49, No. 3 (Summer 1995), pp. 379-414; and Jonathan Mercer, "Rationality and Psychology in International Politics," International Organization, Vol. 59, No. 1 (Winter 2005), pp. 77-106.

5. Robert Jervis, Perception and Misperception in International Politics (Princeton, N.J.: Princeton University Press, 1976); Rose McDermott, Political Psychology in International Relations (Ann Arbor: University of Michigan Press, 2004); David O. Sears, Leonie Huddy, and Robert Jervis, eds., Oxford Handbook of Political Psychology (Oxford: Oxford University Press, 2003); Jack S. Levy and William R. Thompson, Causes of War (Oxford: Wiley-Blackwell, 2010); Monica Duffy Toft, The Geography of Ethnic Violence: Identity, Interests, and the Indivisibility of Territory (Princeton, N.J.: Princeton University Press, 2003); Jonathan Mercer, Reputation and International Politics (Ithaca, N.Y.: Cornell University Press, 1996); and David A. Welch, Justice and the Genesis of War (Cambridge: Cambridge University Press, 1993).

6. Blainey, The Causes of War, p. 35; and Stephen Van Evera, Causes of War: Power and the Roots of Conflict (Ithaca, N.Y.: Cornell University Press, 1999), p. 16. See also Dominic D.P. Johnson, Overconfidence and War: The Havoc and Glory of Positive Illusions (Cambridge, Mass.: Harvard University Press, 2004); Daniel Kahneman and Jonathan Renshon, "Why Hawks Win," Foreign Policy, No. 158 
overestimate the probability of victory and the likely spoils of war, provoking wars that could otherwise be avoided and risking battlefield defeat against superior opponents. ${ }^{7}$ But despite copious evidence associating overconfidence with war, the causal relationship between these variables remains underdeveloped. ${ }^{8}$ In particular, scholars need to understand why and when overconfidence varies; otherwise, it cannot explain fluctuations in war and peace. This article identifies a novel and significant source of variation in overconfidence: deliberative versus implemental mind-sets.

Fifth, the Rubicon theory explains important patterns and anomalies in the origins of World War I, in particular, the pronounced rise in confidence on the eve of war, as the European great powers crossed their respective (psychological) Rubicons.

(January/February 2007), pp. 34-38; Barbara W. Tuchman, The March of Folly: From Troy to Vietnam (New York: Alfred A. Knopf, 1984); and Dominic D.P. Johnson, Rose McDermott, Emily S. Barrett, Jonathan Cowden, Richard W. Wrangham, Matthew H. McIntyre, and Stephen Peter Rosen, "Overconfidence in Wargames: Experimental Evidence on Expectations, Aggression, Gender, and Testosterone," Proceedings of the Royal Society of London, Series B, October 7, 2006, pp. 2513-2520. 7. In this article, we define "confidence" as the perceived probability that a specified outcome will occur. For example, low confidence may equate with a belief that one has a 25 percent chance of victory, whereas high confidence may equate with a belief that one has a 75 percent chance of victory. "Overconfidence" is defined as a level of confidence that exceeds the true likelihood of an outcome. For example, if a tennis player expects to win 75 percent of his or her matches but loses them all, this would imply overconfidence. The notion of overconfidence is sometimes criticized because it appears to require post hoc judgments. How do we know the true likelihood of an outcome? This is not as large a problem as it may seem, for five reasons. First, although it is problematic to estimate each side's true likelihood of winning at the outbreak of war, these estimates are not entirely subjective or arbitrary. In many cases, overconfidence is so extreme (i.e., "we will win in a few days"), and so far removed from a reasonable assessment of the available evidence, that labeling it as such is straightforward. Second, the true likelihood of an outcome is usually estimated by many observers, both inside and outside the countries concerned, so estimates that are far more confident than the average are likely to be overconfident. Third, there is often strong evidence that accurate information was available to leaders, but was discounted or ignored out of hand, suggesting overconfident beliefs. Fourth, the actual outcome is typically known, providing evidence about whether decisionmakers made a good bet or not. If the tape of history were rerun, they may be right on another occasion, but one data point is nevertheless better than none. On average, expecting a lot and gaining little implies overconfidence. Fifth, when both or all sides think they will resoundingly crush their adversaries, this is a good sign that at least one of the sides is overconfident.

8. Even Fearon's widely cited 1995 article "Rationalist Explanations for War" opens up a potentially important role for overconfidence. Fearon argues that a central cause of war within the rational choice framework is a leader's private information about their own side's resolve or strength, plus "an incentive to exaggerate their true willingness or capability to fight" (p. 395). Poor information may lead to spurious overvaluation-even by a rational actor-of one's own capabilities relative to the opponent, or undervaluation of an adversary's true interests in the outcome of a conflict. Fearon suggests that leaders consciously withhold private information from adversaries, for good reason; but this makes the adversary more likely to choose war, as he cannot accurately assess his opponent's strength. Another possibility, however, suggested by the Rubicon theory of war, is that leaders make inaccurate judgments about relative capabilities and interests because of psychological biases such as overconfidence. This may occur in addition to, or instead of, the phenomena proposed by Fearon. 
Sixth, the theory has important policy implications. Because psychological biases are difficult for individuals to resist, or even acknowledge, leaders must build policymaking routines or institutional structures that guard against the negative effects of implemental mind-sets. They must also recognize that opponents may adopt implemental mind-sets and become more overconfident when conflict draws near, increasing the possibility of deterrence failure, escalation, and war.

The article has five sections. First, we highlight puzzling historical examples where confidence increased on the eve of war. Second, we describe the "Rubicon model of action phases" developed in psychology. Third, we apply the Rubicon model to international conflict and derive several novel hypotheses on the relationship between mind-sets and war. Fourth, we explore our hypotheses with a study of World War I. Fifth, we discuss the implications of the argument for international relations theory and practice.

\section{The Puzzle of Overconfidence and War}

A number of historical cases suggest a puzzling phenomenon about war: confidence rises as conflict draws near. This is surprising because, from a rationalist perspective, as long as capabilities and environmental factors remain the same, the actual probability of winning should not alter simply because the event is closer in time.

At various moments during the 1938 Munich crisis, for example, France weighed its chances of defeating Germany. ${ }^{9}$ French leaders were far more confident about victory when they thought that war was imminent, and far less confident of victory when they thought that war could be avoided. Herbert Dinerstein wrote that when Prime Minister Edouard Daladier "felt that France could not fight, then the French air force was terrible. When he felt that France had to fight, then the French air force was not so bad, and quite without basis, he included 5,000 Russian planes on the French side." ${ }^{\prime 10}$

It was not just the French who exhibited this pattern during 1938. Thomas Inskip, the British minister for the coordination of defense, was initially cautious about the likely outcome of war. But after Adolf Hitler made a series of outrageous demands and war loomed, Inskip determined that the military sit-

9. The Munich crisis occurred after Germany demanded the annexation of the Sudetenland area of Czechoslovakia. The crisis was resolved peacefully when Britain and France agreed to the substance of the German wishes as part of the policy of appeasement.

10. Herbert S. Dinerstein, "The Impact of Air Power on the International Scene, 1933-1940," Military Affairs, Vol. 19, No. 2 (Summer 1955), pp. 65-71, at p. 70; and Jervis, Perception and Misperception in International Politics, p. 138. 
uation was "more favorable than we had previously thought."11 Similarly, when war appeared imminent on September 23, the British chiefs of staff produced a far more positive assessment of the strategic environment than before, noting their "confidence as to the ultimate outcome" of war. ${ }^{12}$

Indeed, Wesley Wark's study of British prewar intelligence noted four distinct phases in which optimism about war with Germany waxed and waned during the 1930s. Although some of this variation tracked differences in intelligence estimates (as rational choice approaches would predict), Wark stressed that there was also a psychological factor shaping the selection and interpretation of intelligence. Once war looked inevitable by 1939, the same actors that had previously been gloomy about the odds of military success became significantly more optimistic about "surviving a knockout blow and going on to crush Nazi Germany." 13 The key variable that changed was not the military balance but rather the likelihood of war. As Wark notes, "A dramatic shift of perspective, rather than any real improvement in the numerical ratio of forces, was at work ... . [which] can only be described as a remarkable recovery of confidence and a fresh appraisal of military facts."14 Janice Gross Stein concurs: "In 1939, when the scope of Hitler's ambitions became unmistakably apparent, estimates of relative German capabilities declined as British leaders prepared for war."15

The same pattern appears to hold with public, as well as elite, opinion. In the months leading up to the 1991 Persian Gulf War, the American public was repeatedly asked whether they thought a war between the United States and Iraq would be short or long in duration. Figure 1 shows that during the fall of 1990, when war remained uncertain, public confidence drifted slightly downward, with around 60 percent expecting a short war and about 35 percent expecting a long war. But once conflict looked imminent in the first weeks of January 1991, confidence that the war would be short increased dramatically. On January 16, the day Operation Desert Storm began, 83 percent of Americans expected a short war, and only 13 percent expected a long war.

One explanation for rising confidence in 1991 might be changing patterns of information. Perhaps a spike in media coverage on the eve of war simply re-

11. Quoted in Williamson Murray, The Change in the European Balance of Power, 1938-1939: The Path to Ruin (Princeton, N.J.: Princeton University Press, 1984), p. 207.

12. Ibid., p. 210; and Peter Neville, Winston Churchill: Statesman or Opportunist? (London: Hodder and Stoughton, 1996).

13. Wesley K. Wark, The Ultimate Enemy: British Intelligence and Nazi Germany, 1933-1939 (Ithaca, N.Y.: Cornell University Press, 1985), p. 233.

14. Ibid., p. 240.

15. Janice Gross Stein, "Building Politics into Psychology: The Misperception of Threat," Political Psychology, Vol. 9, No. 2 (June 1988), pp. 245-271, at p. 259. 
Figure 1. Dramatic Increase in Public Confidence About the Success of the 1991 Gulf War as War Became Imminent. (Data show responses to the question: "Do you think the war between the United States and Iraq would be a relatively short war lasting a few weeks or months or do you think such a war would last for a long time, a year or more?" ABC News / Washington Post polls, 1990-91. Polling data from http://www.LexisNexis.com.)

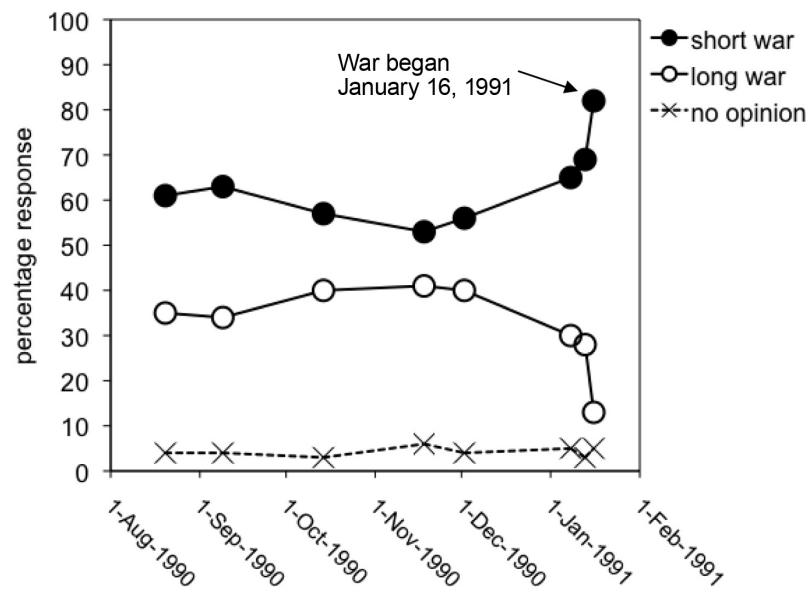

vealed to Americans what was true all along - that the mission would be relatively straightforward. Alternatively, people may have inferred that President George H.W. Bush would have decided to fight only if the war would be quick and relatively costless.

Such logic, however, cannot easily explain a surge in confidence on the eve of war when that confidence is unwarranted. For example, in 2003, regime change in Iraq might have been relatively straightforward, but postwar stabilization was likely to be difficult and protracted. Nevertheless, as the invasion drew near, Americans concluded that success in both of these objectives would be swift. Figure 2 shows that, in the months leading up to the conflict, a majority expected "a long and costly involvement" in Iraq. But judgments switched immediately before the war, such that a majority now expected "a fairly quick and successful effort."

\section{The Rubicon Model of Action Phases}

How can we explain this puzzling spike in confidence on the eve of war? One intriguing answer comes from experimental psychology. A classic study from the 1960s found that as soon as people had placed their bets at a racetrack, they 
Figure 2. Dramatic Increase in Public Confidence About the Success of the 2003 Iraq War as War Became Imminent. (Data show responses to the question: "If the United States does get militarily involved in Iraq, which of the following would be the most likely: a fairly quick and successful effort, or a long and costly involvement?" CBS News polls, 2002-03. Polling data from http:// www.LexisNexis.com.)

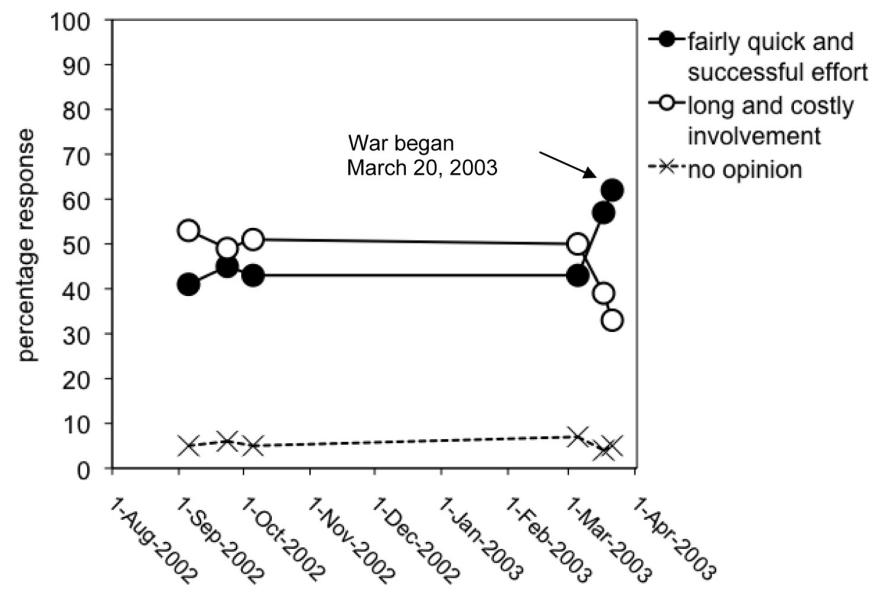

suddenly grew more confident that their horse would win. ${ }^{16}$ The simple act of committing to a decision altered their assessment of the probability of success. A series of subsequent studies replicated the same phenomenon in widely different circumstances, triggering a major research program in psychology. To explain the remarkable switch in people's cognitive processing before and after making a decision, psychologists Heinz Heckhausen and Peter Gollwitzer proposed the "Rubicon model of action phases," named after Caesar's fateful choice of 49 в.с. ${ }^{17}$

The Rubicon model posits that the decisionmaking process follows a series of distinct stages, each of which activates a particular mind-set, or cognitive orientation. A "deliberative" mind-set dominates the predecisional phase, when options and possible outcomes are weighed and compared. An "implemental" mind-set dominates the postdecisional phase, when the focus shifts to

16. Robert E. Knox and James A. Inkster, "Postdecision Dissonance at Post Time," Journal of Personality and Social Psychology, Vol. 8, No. 4 (1968), pp. 319-323.

17. Heinz Heckhausen and Peter M. Gollwitzer, "Thought Contents and Cognitive Functioning in Motivational versus Volitional States of Mind," Motivation and Emotion, Vol. 11, No. 2 (June 1987), pp. 101-120. For a recent overview of the development of the Rubicon model, its empirical support, and how it has influenced the field of psychology, see Gollwitzer, "Mindset Theory of Action Phases." 
carrying out the chosen course of action. Importantly, the shift from a deliberative to an implemental mind-set can occur either when an actor freely chooses a policy from a menu of options, or when a course of action is dictated by an external source: "[W]hat matters is that one feels called upon to implement a certain goal, regardless of whether it is chosen or assigned." 18 The metaphor of crossing the Rubicon refers to the moment when deliberations have, for whatever reason, been put to rest.

The reason the Rubicon model is so important is that people exhibit a dramatic difference in their susceptibility to judgment and decisionmaking biases depending on whether they are in a deliberative or an implemental mind-set. As Heckhausen and Gollwitzer found, the "transition from contemplating to enacting options appears to represent a psychological Rubicon, a boundary line between different states of mind."19

\section{DELIBERATIVE VERSUS IMPLEMENTAL MIND-SETS}

Table 1 summarizes key biases that differ significantly between people in a predecisional or deliberative mind-set versus a postdecisional or implemental mind-set. Actors in a deliberative mind-set (left column of table 1) adopt a relatively objective approach to judgment and decisionmaking, weighing the expected utility of different options in an effort to make the best selection. In deliberative mind-sets, people may approximate the rational actor model of decisionmaking.

By contrast, judgment and decisionmaking are very different in an implemental mind-set, which occurs when actors plan how to implement their chosen course of action or actually engage in implementation (right column of table 1). The task now is to prepare for the achievement of certain goals and avoid being distracted by alternatives or doubts. Actors in an implemental mind-set become committed to the course of action that has been chosen or forced on them. They focus intensely on getting the task done and resist reconsidering decisions they have already made or contemplating other courses of action. ${ }^{20}$ As Heckhausen and Gollwitzer put it, implemental mind-sets turn people into "narrow-minded partisans of their plans of action." ${ }^{21}$ People in

18. Heckhausen and Gollwitzer, "Thought Contents and Cognitive Functioning in Motivational versus Volitional States of Mind," p. 118.

19. Ibid., p. 120.

20. Shelley E. Taylor and Peter M. Gollwitzer, "Effects of Mindset on Positive Illusions," Journal of Personality and Social Psychology Bulletin, Vol. 69, No. 2 (August 1995), pp. 213-226.

21. Heckhausen and Gollwitzer, "Thought Contents and Cognitive Functioning in Motivational versus Volitional States of Mind," p. 103. 
Table 1. Psychological Differences between Deliberative versus Implemental Mind-Sets. (Implemental mind-sets promote several biases that have the overarching effect of increasing overconfidence.)

\begin{tabular}{llll}
\hline & & \multicolumn{1}{c}{ Mind-Set } \\
\cline { 3 - 4 } Phenomenon & $\begin{array}{l}\text { Deliberative } \\
\text { (predecisional) }\end{array}$ & $\begin{array}{l}\text { Implemental } \\
\text { (postdecisional) }\end{array}$ \\
\hline 1 & Receptivity to incoming information & higher & lower \\
2 & Processing of incoming information & less biased & more biased \\
3 & Vulnerability to cognitive dissonance & lower & higher \\
4 & Vulnerability to self-serving evaluations & lower & higher \\
5 & Vulnerability to illusion of control & lower & higher \\
6 & Expectations of task & more realistic & more optimistic \\
& & - & V \\
& Overarching effect: & less overconfidence & more overconfidence \\
\hline
\end{tabular}

implemental mind-sets are especially likely to deviate from a rational model of decisionmaking —in six specific dimensions. ${ }^{22}$

RECEPTIVITY TO NEW INFORMATION. Actors in an implemental mind-set adopt a kind of "tunnel vision," paying more attention to the tasks with which they are occupied and being less receptive to other information received in the meantime. In particular, they display a reduced receptivity to new information that may question the desirability or feasibility of the chosen goal. ${ }^{23}$ Instead, they seek information that supports the choice already made. ${ }^{24}$ Psychologists developed paradigms to experimentally manipulate subjects into deliberative mind-sets (e.g., by having the subject choose between tests they must take or

22. Psychological phenomena are often categorized as either "motivated" biases (deriving from people's beliefs, preferences, and desires dominating rational thought) or "cognitive" biases (deriving from the machinery of how the brain works). Cognitive biases are generally thought to operate at most times, whereas motivated biases are more likely to occur when people's beliefs and preferences come under challenge. The biases in table 1 would primarily be classified as motivated biases. In implemental mind-sets-when attention turns to carrying out a chosen course of action-personal stakes come to the fore and motivated biases are likely to rise in prominence. For reviews of motivational and cognitive biases, see Irving L. Janis and Leon Mann, Decision Making: A Psychological Analysis of Conflict, Choice, and Commitment (New York: Free Press, 1979); and Jervis, Perception and Misperception in International Politics. For important predictive differences between motivational and cognitive biases, see Chaim D. Kaufmann, "Out of the Lab and into the Archives: A Method for Testing Psychological Explanations of Political Decision Making," International Studies Quarterly, Vol. 38, No. 4 (December 1994), pp. 559-560.

23. Heckhausen and Gollwitzer, "Thought Contents and Cognitive Functioning in Motivational versus Volitional States of Mind."

24. Jurgen Beckmann and Peter M. Gollwitzer, "Deliberative versus Implemental States of Mind: The Issue of Impartiality in Predecisional and Postdecisional Information Processing," Social Cognition, Vol. 5, No. 3 (1987), pp. 259-279. 
deliberate important unresolved problems) and implemental mind-sets (e.g., by having the subject plan how to perform a given test). Studies found that subjects in an implemental mind-set showed significantly lower working memory capacity than participants in a deliberative mind-set and reduced open-mindedness toward new information. ${ }^{25}$ Overall, deliberative mind-sets lead to "cognitive tuning" that attends to information on the feasibility and desirability of possible options, whereas implemental mind-sets lead to cognitive tuning that attends to information on how to carry out the chosen option. ${ }^{26}$

PROCESSING OF INFORMATION. In addition to being less receptive to new information, actors in an implemental mind-set tend to process the information they do receive in a selective and one-sided way, supporting the course of action in which they are already engaged. Information on desirability and feasibility is handled fairly impartially and accurately in a deliberative mind-set, whereas people become biased and overoptimistic in an implemental mindset. ${ }^{27}$ In one study, subjects manipulated into a deliberative mind-set reported the potential positive and negative consequences of their options with equal frequency, whereas those manipulated into an implemental mind-set were less likely to reflect on the pros and cons of a chosen goal at all, and when they did, the consideration of pros was five times more frequent than the consideration of cons. ${ }^{28}$ Actors in implemental mind-sets also show evidence of "defensive" processing of information that threatens their course of action. ${ }^{29}$

VULNERABILITY TO COGNITIVE DisSONANCE. Actors in an implemental mindset are also prone to cognitive dissonance, where information that contradicts a cherished or established belief generates psychological discomfort or "dissonance." As a result, people subconsciously try to make contradictory information fit their existing beliefs, or they avoid situations that may increase dissonance, or both. Experimental studies have shown that subjects in an implemental mind-set tend to exhibit an exaggerated version of the classic

25. Heckhausen and Gollwitzer, "Thought Contents and Cognitive Functioning in Motivational versus Volitional States of Mind," study 2; Kentaro Fujita, Peter M. Gollwitzer, and Gabriele Oettingen, "Mindsets and Pre-Conscious Open-Mindedness to Incidental Information," Journal of Experimental Social Psychology, Vol. 43, No. 1 (January 2007), pp. 48-61; Beckmann and Gollwitzer, "Deliberative versus Implemental States of Mind"; and Peter M. Gollwitzer and Ute Bayer, "Deliberative versus Implemental Mindsets in the Control of Action," in Shelly Chaiken and Yaacov Trope, eds., Dual-Process Theories in Social Psychology (New York: Guilford, 1999), pp. 403-422. 26. Peter M. Gollwitzer, Heinz Heckhausen, and Birgit Steller, "Deliberative and Implemental Mind-Sets: Cognitive Tuning toward Congruous Thoughts and Information," Journal of Personality and Social Psychology, Vol. 59, No. 6 (December 1990), pp. 1119-1127.

27. Gollwitzer, "Mindset Theory of Action Phases."

28. Taylor and Gollwitzer, "Effects of Mindset on Positive Illusions," study 3.

29. Faby M. Gagné and John E. Lydon, "Mindset and Relationship Illusions: The Moderating Effects of Domain Specificity and Relationship Commitment," Personality and Social Psychology Bulletin, Vol. 27, No. 9 (September 2001), pp. 1144-1155. 
"spreading of alternatives" - where chosen options seem more preferable than before, and rejected options appear less preferable than before. ${ }^{30}$

VULNERABILITY TO SELF-SERVING EVALUATIONS. The transition from deliberative to implemental mind-sets is also associated with a shift from more objective views of one's capabilities to self-serving illusions. There is a general tendency among all mentally healthy adults to see themselves as more skilled or capable than they really are. ${ }^{31}$ Subjects in an implemental mind-set, however, are especially prone to overly positive self-evaluations and are more likely to report positive attributes such as leadership ability or intellect. ${ }^{32}$

VULNERABILITY TO ILLUSIONS OF CONTROL. Actors in an implemental mindset show increased vulnerability to the "illusion of control," which refers to the tendency to believe that one can control events, even if they are inherently uncontrollable. ${ }^{33}$ In one classic experimental paradigm, subjects are instructed to press a button, and a target light either does or does not switch on. This is repeated many times, after which the subject is asked to estimate how much control they have over the light. In reality, the light is sometimes set to go on or off in connection with button presses, and at other times at random, so subjects have only limited control. Although most people overestimate the degree of control they have over the light, subjects in an implemental mind-set are especially prone to this error. ${ }^{34}$ People in implemental mind-sets are also more likely to perceive themselves to be invulnerable to general everyday riskseven those that can be uncontrollable such as disease or accidents. ${ }^{35}$

EXPECTATIONS OF TASK. Actors in an implemental mind-set are also more optimistic about the likely outcome of tasks. Whereas actors in a deliberative mind-set tend to play "devil's advocate," carefully tallying the likely positive and negative effects, actors in an implemental mind-set are more

\footnotetext{
30. Eddie Harmon-Jones and Cindy Harmon-Jones, "Testing the Action-Based Model of Cognitive Dissonance: The Effect of Action Orientation on Postdecisional Attitudes," Personality and Social Psychology Bulletin, Vol. 28, No. 6 (June 2002), pp. 711-723; Joel Cooper, Cognitive Dissonance: Fifty Years of a Classic Theory (New York: Sage, 2007); and Leon Festinger, A Theory of Cognitive Dissonance (Stanford, Calif.: Stanford University Press, 1957).

31. Shelley E. Taylor and Jonathan D. Brown, "Illusion and Well-Being: A Social Psychological Perspective on Mental Health," Psychological Bulletin, Vol. 103, No. 2 (March 1988), pp. 193-210.

32. Taylor and Gollwitzer, "Effects of Mindset on Positive Illusions," study 2; and Gollwitzer and Bayer, "Deliberative versus Implemental Mindsets in the Control of Action."

33. Taylor and Brown, "Illusion and Well-Being"; and Shelley E. Taylor, "Positive Illusions," in Howard S. Friedman, ed., Encyclopedia of Mental Health, Vol. 3 (San Diego, Calif.: Academic Press, 1998), pp. 199-208.

34. Peter M. Gollwitzer and Ronald F. Kinney, "Effects of Deliberative and Implemental Mind-Sets on Illusion of Control," Journal of Personality and Social Psychology, Vol. 56, No. 4 (April 1989), pp. 531-542; and Gollwitzer and Bayer, "Deliberative versus Implemental Mindsets in the Control of Action," pp. 412-413.

35. Taylor and Gollwitzer, "Effects of Mindset on Positive Illusions," study 1.
} 
sanguine about the probable results and exhibit a more upbeat overall mood. ${ }^{36}$ Studies have shown that subjects in implemental mind-sets are more likely to opt for overly difficult tasks, overestimate their probability of achieving these tasks, and make fewer references to past failures. ${ }^{37}$

\section{OVERARCHING EFFECT: OVERCONFIDENCE}

Implemental mind-sets produce or amplify the six major biases outlined above. Although each of these biases has unique effects, all of them contribute to an important overarching phenomenon: overconfidence. Most mentally healthy adults display overconfident biases, for example, exaggerating their perceived qualities and capabilities, maintaining an illusion of control, and believing they are invulnerable to risk. ${ }^{38}$ Crucially, however, overconfidence increases systematically-above any baseline level-when people shift from a deliberative to an implemental mind-set. In a deliberative mind-set, overconfidence may be present but limited as actors carefully weigh their strengths, the opportunities and threats presented by the environment, and the likely success of different available options. Switching from a deliberative to an implemental mind-set, however, triggers the six biases in table 1, which converge to produce a spike in overconfidence. ${ }^{39}$ As Gollwitzer summed it up, "[C]hoosing between action goals leads to realism, and implementing chosen goals leads to positive illusions." 40

\section{Application to International Relations: The Rubicon Theory of War}

What are the implications of the Rubicon model of action phases for international relations? The switch from deliberative to implemental mind-sets may

36. David A. Armor and Shelley E. Taylor, "The Effects of Mindset on Behavior: Self-Regulation in Deliberative and Implemental Frames of Mind," Personality and Social Psychology Bulletin, Vol. 29, No. 1 (January 2003), pp. 86-95; Gollwitzer and Bayer, "Deliberative versus Implemental Mindsets in the Control of Action," pp. 411-414; and Taylor and Gollwitzer, "Effects of Mindset on Positive Illusions."

37. Rosa M. Puca, "Preferred Difficulty and Subjective Probability in Different Action Phases," Motivation and Emotion, Vol. 25, No. 4 (December 2001), pp. 307-326. See also Veronika Brandstätter and Elisabeth Frank, "Effects of Deliberative and Implemental Mindsets on Persistence in GoalDirected Behavior," Personality and Social Psychology Bulletin, Vol. 28, No. 10 (October 2002), pp. 1366-1378.

38. Overconfidence also varies according to personality type, gender, and characteristics of the decisionmaking environment. Taylor and Brown, "Illusion and Well-Being"; Taylor, "Positive Illusions"; Shelley E. Taylor, Jennifer S. Lerner, David K. Sherman, Rebecca M. Sage, and Nina K. McDowell, "Portrait of the Self-Enhancer: Well Adjusted and Well Liked or Maladjusted and Friendless?" Journal of Personality and Social Psychology, Vol. 84, No. 1 (2003), pp. 165-176; and Johnson, Overconfidence and War.

39. Taylor and Gollwitzer, "Effects of Mindset on Positive Illusions."

40. Gollwitzer, "Mindset Theory of Action Phases," p. 538. 
Figure 3. Proposed Relationship between Mind-Sets, Overconfidence, and War. (When war is perceived as imminent, actors adopt implemental mind-sets, leading to heightened overconfidence and an increase in the probability of war [if war is not already 100 percent certain to occur] and risky war plans [in any setting]. When war is not perceived as imminent, actors adopt deliberative mind-sets and resist these effects.)

intervening variable dependent variable

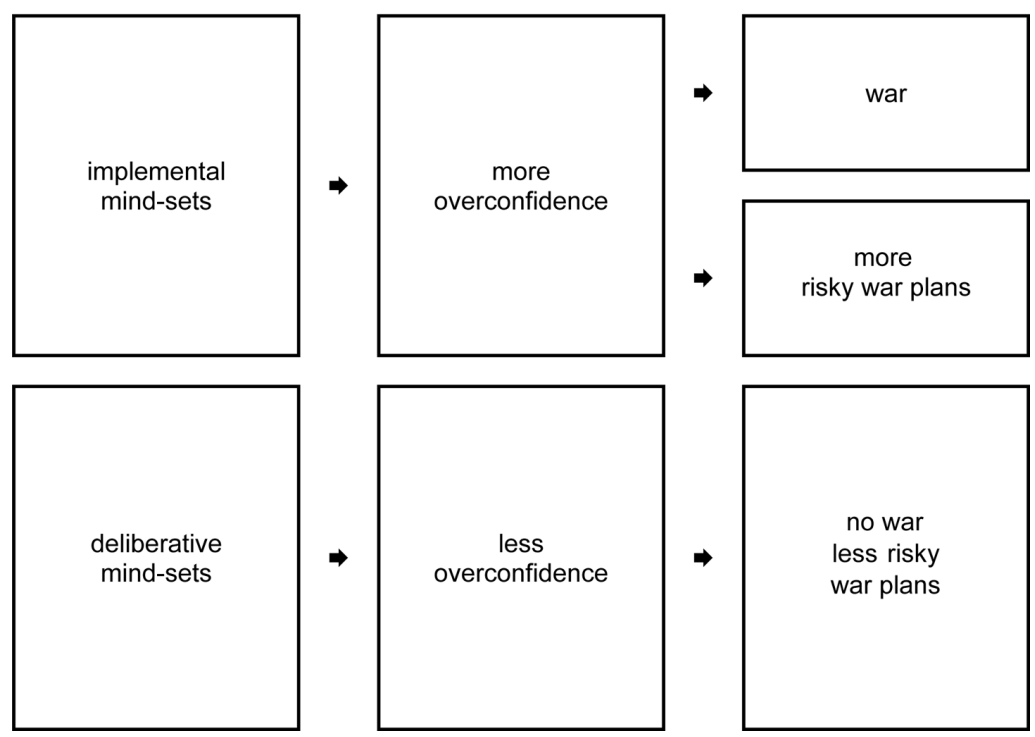

influence politics in a wide range of domains, including election campaigns, economic bargaining, and alliance formation. Here we focus on one key application of the Rubicon model of action phases—to the outbreak of war-which we call the Rubicon theory of war. ${ }^{41}$ Figure 3 summarizes our theory and lays out our independent, intervening, and dependent variables.

The first consideration in translating the Rubicon model to war is to identify

41. Because the Rubicon model of action phases derives in part from laboratory experiments, will these same phenomena be expected to apply to decisionmakers in the real world? The answer is yes because (1) all mentally healthy humans, whether decisionmakers or laypeople, share the same brain architecture, cognitive functioning, and processing mechanisms; (2) empirical evidence shows that even experts fall prey to common psychological biases; and (3) in international crises decisions must be made with little time and limited information, under conditions of stress and high emotions, which tends to exacerbate the effect of psychological biases. See Alex Mintz, Steven B. Redd, and Arnold Vedlitz, "Can We Generalize from Student Experiments to the Real World in Political Science, Military Affairs, and International Relations?" Journal of Conflict Resolution, Vol. 50, No. 5 (October 2006), pp. 757-776; Philip E. Tetlock, Expert Political Judgment: How Good Is It? How Can We Know? (Princeton, N.J.: Princeton University Press, 2005); and Stephen Peter Rosen, War and Human Nature (Princeton, N.J.: Princeton University Press, 2004). 
what causes the shift from a deliberative to an implemental mind-set. The most obvious candidate is making a decision to launch a war. The psychological literature, however, demonstrates that implemental mind-sets can be triggered not only by the choice of an action but also by the imposition of a course of action from some other source. We therefore start with a different assumption: the reason that actors switch from a deliberative to an implemental mindset is the perception that conflict is imminent. This distinction is crucial because-as we show-the perception of imminent war does not imply that war is imminent in reality, allowing us to examine implemental mind-sets as a cause of war as well as a variable that shapes how conflicts are fought.

In international relations, the perception that war is drawing near can result from a number of different events, including: (1) choice-a freely made decision to initiate a war; (2) entrapment-the perception that one has been forced into war (e.g., by invasion, alliance obligations, or the belief that another state will shortly initiate conflict); or (3) turmoil-the perception that states in the system are losing control of the situation, and there is a "slide" into war. In the following sections, we break down the causal chain linking mind-sets and war into testable hypotheses.

HYPOTHESIS 1: IMPLEMENTAL MIND-SETS CAUSE OVERCONFIDENCE ABOUT WAR We predict that actors in an implemental mind-set will be subject to a number of biases in judgment and decisionmaking about war, consistent with the psychological phenomena highlighted in table 1 .

First, actors in an implemental mind-set will be less receptive to new information about the likely costs, benefits, and outcomes of war (table 1,\#1), especially information that contradicts or endangers the chosen (or imposed) course of action. Intelligence information may be discounted or disbelieved. The scope of consultations with the cabinet, or other advisers and policymakers, will narrow and critical voices will be systematically sidelined.

Second, actors in an implemental mind-set will process information about the likely costs, benefits, and outcomes of war in a one-sided and partial manner (table 1, \#2). They will resist thorough consideration of the negative implications of new information and give greater weight to positive information.

Third, actors in an implemental mind-set who receive information suggesting the possibility of high costs, protracted conflict, or defeat are likely to experience intense psychological dissonance (table 1,\#3). They are more likely to downplay, dismiss, or ignore this information, making chosen strategies look better, and alternative strategies worse, than they really are.

Fourth, actors in an implemental mind-set will adopt self-serving illusions 
(table 1, \#4) about the effectiveness of their leadership and decisionmaking and the state's military, economic, moral, or strategic attributes. They are more likely to discount previously perceived weaknesses such as a lack of manpower, weapons, or economic resources.

Fifth, actors in an implemental mind-set will show heightened vulnerability to the illusion of control (table 1,\#5), believing that they can manipulate the international political, economic, and military environment to attain favored ends, despite the inherently complex and unpredictable aspects of war. They will be more sanguine about avoiding random or uncontrollable negative outcomes, and may become more risk prone in the belief that whatever happens, they will be able to maintain the upper hand.

Sixth, actors in an implemental mind-set will be more optimistic about the costs and benefits of the conflict (table 1,\#6). No longer will they play devil's advocate about the inherent dangers of war. Instead, they will tend to conclude that the war will end favorably.

Most important, these six biases converge to produce overconfidence about the outcome of war. When decisionmakers are considering whether or not to fight in a deliberative mind-set, they are likely to weigh the different options in a relatively balanced manner. The switch to an implemental mind-set, however, exposes decisionmakers to the six powerful psychological biases described above, the net effect of which is a sharp increase in overconfidence about the probability of victory.

For a rational actor, the perceived likelihood of conflict should have no impact on the expected probability of victory (assuming all else remains equal). But when human actors perceive conflict as being more likely, their levels of confidence increase. According to the Rubicon theory, people switch into implemental mind-sets; this switch generates an exaggerated belief in military success. The spike in overconfidence is particularly surprising given that confidence might be expected, if anything, to decrease when war is perceived as imminent, because decisionmakers should look with greater care at an event that is seemingly closer in time. One might assume that actors peering over the precipice would consider all the possible elements that can go wrong and become more wary about the outcome. But the closer to the abyss they come, the more eager they are to take the leap.

HYPOTHESIS 2: INCREASES IN OVERCONFIDENCE CAUSE THE OUTBREAK OF WAR We predict that increasing overconfidence resulting from a switch to implemental mind-sets is a cause of war. This prediction assumes that conflict is not already predetermined by other factors. For example, if war is already 100 percent certain when implemental mind-sets arise (e.g., because an aggressor is 
determined to fight), implemental mind-sets on either side may bolster confidence, but they do not increase the probability of war. Absent the switch in mind-set, there would still be war.

If, however, war is perceived as imminent, when it is, in reality, less than 100 percent certain to occur, then implemental mind-sets can be a cause of war. This begs the question of how war can be perceived as imminent when it is, in fact, avoidable. As outlined above, however, the perception that conflict is drawing near can be triggered by several factors beyond choosing war oneself, such as the belief that an adversary is bent on hostilities, that one or both states are locked into an alliance or other commitments, or by the sense that the situation has spun out of control. Perceptions of the adversary's intentions and the degree of control that actors have may be inaccurate. For instance, the notion of the security dilemma suggests that states often exaggerate the hostile intentions of other countries. If state A perceives that state B favors war, even if state B actually prefers peace, state A may falsely conclude that fighting is bound to occur. ${ }^{42}$

In short, there are many reasons why actors may perceive that war is imminent even when it is not. Empirically, this situation might be common, making the Rubicon theory a potentially important explanation of war. As Norrin Ripsman and Jack Levy note, "Although few if any wars are objectively inevitable, psychological factors often induce people to interpret a high probability outcome as certain, and it is striking how frequently perceptions of the inevitability of war appear in the documentary record." ${ }^{\prime 3}$

When war is perceived as imminent but is not in fact 100 percent certain to occur, a shift to an implemental mind-set can increase the probability of conflict-via several pathways. Once decisionmakers perceive that conflict looms, even if in reality it could be avoided, the Rubicon model predicts that they will display the biases in table 1 and become more likely to (1) overestimate the likelihood of victory; (2) overestimate the benefits of war; (3) underestimate the costs of war; (4) believe that they can control events; (5) perceive a negotiated solution as less attractive or less necessary, or both; (6) harden demands; and (7) take provocative steps that make war more probable. All of these effects may push decisionmakers or their adversaries over the brink.

Here, the surge in confidence associated with the perception that war is near occurs at a dangerous moment when peace hangs in the balance. The tragedy of implemental mind-sets is that the perception that war is imminent can be-

42. Jervis, “Cooperation under the Security Dilemma," pp. 167-214.

43. Norrin M. Ripsman and Jack S. Levy, "The Preventive War That Never Happened: Britain, France, and the Rise of Germany in the 1930s," Security Studies, Vol. 16, No. 1 (January 2007), p. 40. 
come a self-fulfilling prophecy: a war that is perceived as being certain to occur becomes certain to occur in reality.

Implemental mind-sets also help to explain why, once a decision for war is made, actors are extremely reluctant to reassess this decision and step back from the brink. There is often a time lag between the decision to fight and the outbreak of hostilities. During this period, putting the brakes on the war machine may be problematic, for example, because mobilization plans are difficult to revise or undo. New information could arise, however, suggesting that war should be postponed or abandoned. Nevertheless, we predict that actors will exhibit a bias against any such reconsideration.

Sometimes, of course, war appears to draw near and yet conflict is nevertheless avoided. This is not a falsification of the theory, only an indication that other variables, if sufficiently strong, can trump the effect of implemental mind-sets. No theory can explain all wars-or all absences of war. Furthermore, overconfidence is bounded, not limitless. If the odds of victory are overwhelmingly negative, then even actors in an implemental mind-set may predict defeat and seek to avoid the use of force. The Rubicon theory holds that, when war is perceived as imminent, actors adopt implemental mind-sets and become more overconfident, making conflict more likely to occur.

\section{HYPOTHESIS 3: INCREASES IN OVERCONFIDENCE CAUSE RISKY MILITARY} PLANNING

We predict that overconfidence resulting from a switch to implemental mindsets is a cause of risky military planning. When leaders are in a deliberative mind-set, they will tend to prepare for war in a relatively cool-headed manner, pay attention to worst-case scenarios, and vigorously debate the merits of different military options.

Once leaders switch to an implemental mind-set, however, planning for war is predicted to display the biases in table 1, which favor bold, aggressive, and even reckless options. First, actors will become partisans of the selected war plan, exhibiting overconfidence that their strategy will deliver rapid victory. They will worry less about the feasibility or desirability of the chosen course. Second, they will be less likely to consult individuals or groups that are doubtful, raise complications, or hold different perspectives. Third, they will resist going back and reconsidering or revising war plans. Fourth, if actors in an implemental mind-set do revise their war plans, these plans are likely to become more ambitious in scope. For example, a state that had decided to use force in a limited fashion may become more confident about the benefits of an expanded war. Fifth, leaders may be reluctant to prepare for a long struggle, for example, by restructuring the country economically. They will avoid or 
downplay contingency planning in case things go badly, including possible exit strategies. In their implemental mind-set, there is less apparent need to do so.

\section{World War I}

Does the Rubicon theory help to explain war in the real world? One way to answer this question is to look in detail at a historical case. In this section, we provide an analysis of the outbreak of World War I. We chose this case for several reasons. First, making claims about varying levels of confidence requires considerable data about the beliefs of key actors. Given scholars' extensive research on World War I, this is a case where the relevant data are available.

Second, the case includes multiple observations: different actors, in six states, with three measurements (changes in overconfidence over time and the effect of overconfidence on the outbreak of war and on war planning). ${ }^{44}$

Third, there are important outstanding puzzles about the path to war in 1914 that the Rubicon theory can, for the first time, explain. If, as many scholars argue, Germany and Austria-Hungary perceived a "window of opportunity" for a successful war in July 1914, why did the Entente powers, presumably suffering from a "window of vulnerability," not try to delay the conflict? Such behavior is hard to understand with existing theories, but it is directly explained by the Rubicon theory of war, which predicts a shift to implemental mind-sets and overconfidence on all sides when fighting drew near in 1914.

Fourth, there has been a long-standing debate about whether or not the European powers were overconfident about victory prior to World War I, and whether this was a cause of the war. Various scholars have championed evidence of overconfidence, whereas others have pointed to an absence of overconfidence or even pessimistic views of war. ${ }^{45}$ How can we account for such diametrically opposed observations? The Rubicon model may help to resolve this argument, because it predicts that overconfidence systematically varies at different points during a crisis. Overconfidence is diminished when war is perceived as distant or hypothetical; it is heightened when war is perceived as imminent.

44. Gary King, Robert O. Keohane, and Sidney Verba, Designing Social Inquiry: Scientific Inference in Qualitative Research (Princeton, N.J.: Princeton University Press, 2001).

45. For evidence of overconfidence, see Van Evera, Causes of War; Mark Hewitson, Germany and the Causes of the First World War (Oxford: Berg, 2004); and Barbara W. Tuchman, The Guns of August (New York: Macmillan, 1962). For evidence of pessimism, see Keir A. Lieber, "The New History of World War I and What It Means for International Relations Theory," International Security, Vol. 32, No. 2 (Fall 2007), pp. 155-191. 
One potential criticism is that World War I is a case where war did ultimately break out, and so we cannot test whether implemental mind-sets occur in crises where war is nevertheless avoided. Our purpose, however, is to demonstrate the plausibility of the Rubicon model as a cause of conflict and risky military planning, which requires a case of war. ${ }^{46}$ Furthermore, evidence discussed earlier suggests that even in crises that do not result in war, such as the Munich crisis, the perception of imminent war led to increasing confidence levels. Here, peace may have been maintained because (1) certain key actors did not see war as imminent and remained in a deliberative mind-set, or (2) other factors trumped the effects of implemental mind-sets and rising overconfidence, and prevented war from occurring.

How can we show that a psychological bias provides a stronger explanation for behavior than the alternative null model of rational choice? There is a large literature on the challenges raised by this issue as well as the potential solutions. $^{47}$

One methodology proposed by Chaim Kaufmann is to focus on a group of elite decisionmakers. If one assumes that these actors all have access to the same, or at least similar, information, then a rational choice approach predicts that any updates in their beliefs should occur in unison across all members of the group. But if the decisionmakers adopt different beliefs in response to the same information, this suggests that individual psychological biases may be important. ${ }^{48}$

Applying Kaufmann's logic to the Rubicon theory, we would expect decisionmakers who received the same information about probable military success to vary in confidence, depending on whether or not they saw war as imminent (and thus switched into an implemental mind-set). If members of a decisionmaking group see war as imminent at different moments in time, this method is reasonably straightforward to apply. One challenge with the Rubicon theory, however, is that all members of a decisionmaking group may come to see war as imminent at the same moment in time and thus display implemental mind-sets simultaneously. This means we need to show that the group did not rationally update on the basis of new information suggesting that war would be easier than originally thought.

In our case study of World War I, we adapt Kaufmann's approach and test

46. See, for example, Jervis, Perception and Misperception in International Politics, p. 138. On selection bias, see Alexander L. George and Andrew Bennett, Case Studies and Theory Development in the Social Sciences (Cambridge, Mass.: MIT Press, 2004), pp. 22-25.

47. For the classic treatment, see Jervis, Perception and Misperception in International Politics. For reviews of problems and solutions, see McDermott, Political Psychology in International Relations; and Sears, Huddy, and Jervis, Oxford Handbook of Political Psychology.

48. Kaufmann, "Out of the Lab and into the Archives," pp. 561-562. 
the Rubicon theory from two angles. First, where decisionmakers displayed implemental mind-sets and increasing confidence in war, we show that information about the odds of success in war did not change, or that new information emerged suggesting that war would be more costly and more dangerous (rather than less), which should have generated caution rather than overconfidence for a rational actor. Second, we show that groups of decisionmakers in different countries exhibited implemental mind-sets and overconfidence at different moments in time, depending on when they came to see war as imminent-with no obvious alternative rational explanation. Using both of these approaches strengthens our ability to distinguish the Rubicon theory from a rational choice account.

For each state in 1914, we focus on the perceptions of key decisionmakers. The number of these actors varied across countries, and not in a simple correlation with the degree of autocracy. In the relatively democratic United States, for example, one man made the key decisions on war-Woodrow Wilsonwhereas in relatively undemocratic Germany, a number of policymakers played an important role.

If our hypotheses hold true, we would expect to see (1) an increase in implemental mind-sets and overconfidence as war became perceived as imminent in 1914; and in turn (2) an increase in the likelihood of war (assuming that war was, in reality, less than 100 percent certain when implemental mindsets arose); and (3) an increase in the ambition or riskiness of war plans. In the following sections, we examine, first, the Central Powers and, second, the Entente.

\section{THE CENTRAL POWERS}

In 1914 there was growing confidence about the outcome of war in both Austria-Hungary and Germany, which led to more ambitious war plans and may have contributed to the outbreak of war.

HYPOTHESIS 1: IMPLEMENTAL MIND-SETS AND INCREASING OVERCONFIDENCE. In the months before June 1914, decisionmakers in Vienna considered a Balkan war possible because of the rising threat that Serbian nationalism posed to Austria-Hungary's multiethnic empire, but it was far from certain. With Austrian decisionmakers in a deliberative mind-set, the possibility that any conflict with Serbia would draw in Russia was a major concern. Indeed, fears that a European conflict would destroy the monarchy led Emperor Franz Joseph and Foreign Minister Leopold Berchtold to caution against a preventive war. ${ }^{49}$ The hawkish chief of the general staff, Baron Franz Conrad, had 
demanded a preventive war with Serbia many times, including "twentyfive times in 1913 alone," but he had been strongly resisted by civilian decisionmakers. ${ }^{50}$

The perceived imminence of war dramatically altered when heir to the Austrian throne Archduke Franz Ferdinand was assassinated on June 28, 1914. Within forty-eight hours of the assassination, almost all of the key players in Vienna had decided to attack Serbia. The Austro-Hungarian decision was finally confirmed on July $7,1914 .^{51}$

The Rubicon theory predicts that the Austro-Hungarian leadership's perception of imminent war would prompt implemental mind-sets and overconfidence. After the assassination, officials in Vienna grew markedly in confidence about the prospects of war. They denied that Russia would fight, downplayed the consequences of war with Russia if St. Petersburg did fight, or simply ignored the Russian dimension altogether. Consistent with the psychological shifts highlighted in table 1 is William Jannen's observation that "[t]his intense and growing desire to settle with Serbia was frustrated by an almost equal dread of war with Russia. The pressure to escape the stress of such unpalatable alternatives could and did lead to a tendency to seek an illusory way out, for example, to destroy Serbia without war with Russia." ${ }^{2}$ When the leadership considered how the Austro-Hungarian military measured up, they compared it to the militaries of Serbia and Bulgaria, not those of France and Russia. ${ }^{53}$ Indeed, according to Samuel Williamson, once the July crisis erupted, Hapsburg policy "rested on hopes and illusions rather than realistic chances for success." 54

There was one notable skeptic of a military confrontation-the head of the Hungarian government, Count István Tisza. It appears, however, that even this holdout was eventually dragged across the Rubicon, triggering an implemental mind-set. As Miklós Molnár wrote, “Tisza finally relented under pressure from Austrian ministers and with agreement from Berlin. He was then in the front line, concentrating all his efforts on winning the war." 55

son and Peter Pastor, eds., Essays on World War I: Origins and Prisoners of War (New York: Brooklyn College Press, 1983), p. 55.

50. Hew Strachan, The First World War (New York: Viking, 2004), p. 11.

51. Richard F. Hamilton and Holger H. Herwig, Decisions for War, 1914-1917 (Cambridge: Cambridge University Press, 2003), pp. 47, 68.

52. Jannen, "The Austro-Hungarian Decision for War in July 1914," p. 66.

53. Ibid., pp. 55-61.

54. Samuel R. Williamson, Austria-Hungary and the Origins of the First World War (New York: St. Martin's, 1991), p. 208.

55. Miklós Molnár, A Concise History of Hungary (Cambridge: Cambridge University Press, 2001), p. 241. See also William Mulligan, The Origins of the First World War (Cambridge: Cambridge University Press, 2010), pp. 215-216. 
In Berlin, perceptions that war was imminent came later than in Vienna because Germany would not necessarily be directly involved in AustriaHungary's showdown with Serbia. As the crisis escalated in the last two weeks of July, the German leadership saw its involvement in war as becoming more likely, and aimed to manipulate its outbreak on the best possible terms. During this period, the evidence is mixed concerning shifts from a deliberative to an implemental mind-set and associated changes in confidence.

Not all of the major players in Berlin in 1914 grew in confidence as war drew near. Kaiser Wilhelm was notoriously indecisive, vacillating and uncertain, with rapid alterations in mood from elation to pessimism. His delicate nerves, and erratic and impulsive personality, may have trumped the effects of an implemental mind-set. ${ }^{56}$ On July 31, however, Wilhelm commented, "War with Russia appears to me to be imminent and inevitable," and at this point he retained a serious and calm mood, confident that Romania, Bulgaria, and Turkey would join Germany in battle. ${ }^{57}$ The kaiser also famously told the departing German troops in the first week of August, "You will be home before the leaves have fallen from the trees." 58

German Chancellor Theobald von Bethmann Hollweg's state of mind was also complex. Initially, Bethmann thought a European war might be localized to the Balkans, in which case Germany need not fight. ${ }^{59}$ At this time, Bethmann was cautious about the likely outcome of a broader European war, fearing that hostilities would greatly increase the power of his opponents, the Social Democrats, in Germany, and lead to conflict with Britain: "[E]very last Englishman will march against us." 60

On July 27, Bethmann's secretary recorded that "[t]he reports all point to war." ${ }^{\prime 1}$ In the following days, Bethmann's mood alternated. At times, he was fearful and uncertain, declaring, "When the iron dice begin to roll, may God

56. Giles MacDonogh, The Last Kaiser: The Life of Wilhelm II (New York: St. Martin's, 2000).

57. Quoted in Lamar Cecil, Wilhelm II, Vol. 2: Emperor and Exile, 1900-1941 (Chapel Hill: University of North Carolina Press, 1996), p. 206.

58. Quoted in Tuchman, The Guns of August, p. 119. See also L.L. Farrar Jr., "The Short War Illusion: The Syndrome of German Strategy, August-December, 1914," Militärgeschichtliche Mitteilungen (MGM), Vol. 12 (1972), pp. 39-52, at p. 40. Wilhelm did become downcast when Britain entered the war, repeating over and over "so many enemies." Quoted in Cecil, Wilhelm II, p. 209.

59. Strachan, The First World War, p. 21.

60. Quoted in Dale C. Copeland, The Origins of Major War (Ithaca, N.Y.: Cornell University Press, 2000), p. 85. See also Annika Mombauer, Helmuth von Moltke and the Origins of the First World War (Cambridge: Cambridge University Press, 2001), p. 211; Hamilton and Herwig, Decisions for War, p. 85; V.R. Berghahn, Germany and the Approach of War in 1914 (New York: St. Martin's, 1973), p. 191; and Mulligan, The Origins of the First World War, p. 116.

61. Quoted in Copeland, The Origins of Major War, p. 93. 
help us." ${ }^{62}$ On July 29, however, Bethmann thought that the "general public feeling was good in Germany." 63 The next day, he suggested that the Russians and French were unprepared for a general war. ${ }^{64}$ At the beginning of August, Bethmann predicted "a war lasting three, or at the most, four months . . . a violent, but short storm. ${ }^{\prime 65}$ Bethmann added, optimistically, that once France and Britain had been defeated, they would establish friendly relations with Germany and join in a triumvirate "against the Russia colossus."66

Chief of the German general staff Helmuth von Moltke also displayed a mix of pessimism and occasional optimism. For years before 1914, he had been sober in his assessment of a wider war in Europe: "Our own people too will be utterly exhausted, even if we should be victorious." ${ }^{67}$ On July 29, 1914, Moltke wrote to Bethmann to discuss the impending "world war," predicting that the campaign would "destroy civilization in almost all of Europe for decades to come." 68

Although Moltke recognized that the war might be long and tough, he nevertheless wanted to fight immediately. He felt that the incomplete expansion of the Russian and French armies gave Germany the strategic advantage. ${ }^{69}$ Foreign Minister Gottlieb von Jagow claimed after the war that "Moltke's confidence in victory had 'inspired' him . . . during the July crisis."70

In wider German military circles, a significant increase in overconfidence emerged on the eve of war. On August 2, the Bavarian ambassador in Berlin reported, "One can say today that Germany and Austria will be opposed by the whole world in the impending war. Nonetheless, the mood in the military circle here is one of complete confidence." ${ }^{71}$ German military leaders often highlighted evidence supporting an optimistic appraisal of the outcome of

62. Quoted in Konrad H. Jarausch, The Enigmatic Chancellor: Bethmann Hollweg and the Hubris of Imperial Germany (New Haven, Conn.: Yale University Press, 1973), p. 176.

63. Quoted in Copeland, The Origins of Major War, p. 102.

64. David Stevenson, Armaments and the Coming of War: Europe 1904-1914 (Oxford: Clarendon, 1996), p. 407.

65. Quoted in Fritz Fischer, Germany's Aims in the First World War (New York: W.W. Norton, 1967), p. 92. See also Blainey, The Causes of War, pp. 36-37; Van Evera, Causes of War, p. 32; and Farrar, "The Short War Illusion," p. 40.

66. Quoted in Fischer, Germany's Aims in the First World War, p. 92.

67. Quoted in Lieber, "The New History of World War I and What It Means for International Relations Theory," p. 181.

68. Quoted in ibid., p. 183.

69. Holger H. Herwig, "Germany," in Richard F. Hamilton and Herwig, eds., The Origins of World War I (Cambridge: Cambridge University Press, 2004), p. 175.

70. Quoted in Lebow, Between Peace and War, p. 257.

71. Quoted in Mombauer, Helmuth von Moltke and the Origins of the First World War, pp. 209-212, at pp. 211-212. 
war, such as French budgetary problems and lack of manpower, or the possibility that Britain could be detached from the Entente. Mark Hewitson concluded that key German decisionmakers "genuinely did not believe that the Entente powers, given their perceived military inferiority, would be drawn into a European war. Nonetheless, if they were embroiled in such a conflict, German leaders were confident that the Reich and its allies would win." ${ }^{\prime 2}$

HYPOTHESIS 2: OVERCONFIDENCE AND THE OUTBREAK OF WAR. Did implemental mind-sets cause Germany and Austria-Hungary to start World War I? This is a difficult question to answer because causality hinges on the extent to which war was already certain to occur before implemental mind-sets arose. If actors concluded that war was imminent because at least one state was firmly committed to launching a war, then implemental mind-sets likely played no causal role. By contrast, if actors assumed that war was imminent when in fact it was still avoidable, then implemental mind-sets may have been an important cause of the war.

Scholars fiercely debate whether Germany and Austria-Hungary were committed to fight, and the issue will not be settled here. One historiographical school holds that the two countries deliberately orchestrated the outbreak of World War I. We are sympathetic to this interpretation, which has grown in influence in recent years. ${ }^{73}$ According to the argument, almost as soon as Archduke Franz Ferdinand was assassinated on June 28, Austria-Hungary determined that this was an opportunity to settle decisively with its enemy Serbia and save the multinational empire. As Richard Hamilton and Holger Herwig concluded, "[I]n July 1914 Austria-Hungary's leaders were the first to opt for war, and they did so with plan and foresight." ${ }^{\prime 74}$ Germany may also have seen its interests being served by war. If Russia backed down, a brief and victorious conflict against Serbia could destroy the Entente and end Germany's "encirclement." If Russia made a stand, key players in the German leadership saw the opportunity for a preventive war. ${ }^{75}$

If Austria-Hungary and Germany both pressed for war, then implemental mind-sets, and the associated increase in confidence, only pushed these states farther down the road they already wished to travel. Nevertheless, even here, implemental mind-sets could explain why, once the Austro-Hungarians de-

72. Hewitson, Germany and the Causes of the First World War, p. 217.

73. Lieber, "The New History of World War I and What It Means for International Relations Theory"; Jack Snyder, "Correspondence: Defensive Realism and the 'New' History of World War I," International Security, Vol. 33, No. 1 (Summer 2008), pp. 174-185; and Fischer, Germany's Aims in the First World War.

74. Hamilton and Herwig, Decisions for War, p. 47.

75. Copeland, The Origins of Major War; and Mombauer, Helmuth von Moltke and the Origins of the First World War. 
cided on war with Serbia, they made little or no effort to reassess this decision and step back from the brink. When new information emerged about the likely nature of the war, challenging Austro-Hungarian assumptions, there was little serious attempt to consider whether the use of force ought to be postponed or abandoned. The same logic holds true for Germany, where "civilian decisionmakers could have stopped the crisis from escalating until the very outbreak of war." 76

The second school of historiography holds that Germany and AustriaHungary were not committed to fight, and instead there was a "slide to war" despite the preference for peace among the great powers. If mutual misperceptions, beliefs in the advantages of the offensive, alliance dynamics, domestic politics, or myriad other factors proposed as causal variables in 1914 were indeed important, then implemental mind-sets and associated overconfidence may have been a necessary condition for World War I, pushing actors over the edge when war could otherwise have been averted. ${ }^{77}$ The European states may have exaggerated the extent to which their rivals were already committed to war and, believing hostilities were imminent, become more confident about choosing war themselves. L.L. Farrar claims that in 1914, "[t]he assumption that war would be short was perhaps a precondition for decisions to resort to war in pursuit of pre-war objectives. . . . The short war assumption was therefore a necessary precondition for decisions to resort to war." 78

HYPOTHESIS 3: OVERCONFIDENCE AND RISKY WAR PLANS. Once conflict was perceived as imminent, and actors grew in confidence, war planning became more reckless. Vienna recognized the risk that an attack on Serbia could escalate into a broader European war, but accepted this possibility with remarkable alacrity and fatalism. On July 5, German Undersecretary of State Arthur Zimmerman told Count Alexander Hoyos, chief of staff at the Austrian foreign ministry, that there was a "90 percent probability of a European war if you take action against Serbia." 79

At a key meeting on July 19, Graydon Tunstall described the "curious,

76. Lieber, "The New History of World War I and What It Means for International Relations Theory," p. 188.

77. For discussion of these alternative theories, see Annika Mombauer, The Origins of the First World War: Controversies and Consensus (London: Longman, 2002); Mulligan, The Origins of the First World War; and Steven E. Miller, Sean M. Lynn-Jones, and Stephen Van Evera, eds., Military Strategy and the Origins of the First World War, rev. and exp. (Princeton, N.J.: Princeton University Press, 1991).

78. Farrar, "The Short War Illusion," p. 43.

79. Quoted in John C.G. Röhl, "Germany," in Keith Wilson, ed., Decisions for War, 1914 (New York: St. Martin's, 1995), p. 37. 
astonishing" failure of the Austro-Hungarian leadership to even discuss the consequences of Russian intervention. ${ }^{80}$ On July 29, writes Jannen, "AustroHungarian newspapers were beginning to perceive the growing Russian firmness, but that did not weaken their determination to make war on Serbia. The Budapest Pester-Lloyd said it all: 'Austria-Hungary has burned her bridges, and no power on earth could change her course, not even her own will.'" 81

An implemental, "tunnel vision," focus on crushing Belgrade led to a neglect of the Russian threat and disastrous military planning. Conrad became obsessed with destroying Serbia. He ignored intelligence on Russian mobilization and deployed the reserve Second Army (one cavalry and twelve infantry divisions) to the Serbian front-far away from the Russian border. When Russia advanced into Galicia, Conrad was forced to switch plans and redirect Austrian troops north. The result was chaos and a disastrous military defeat. ${ }^{82}$

Although the evidence of overconfidence in Germany in July 1914 is mixed, exaggerated optimism appears to have infected Berlin's war planning. In 1910 and again in 1912, the German general staff warned that a campaign against France would be long and tough, requiring considerable stockpiles of supplies and ammunition. ${ }^{83}$ In 1912 Col. Erich Ludendorff, who headed the mobilization section of the German general staff, and Moltke advised the war ministry to prepare for a prolonged conflict: "We will have to be ready to fight a lengthy campaign with numerous hard, lengthy battles until we can defeat [even] one of our enemies.... The need for a great deal of ammunition over a long period of time is absolutely critical." 84

When war approached in July 1914, however, Germany failed to prepare the logistics necessary for a long struggle. ${ }^{85}$ Martin van Creveld notes that although "[i]n 1914, the number of rounds [per rifle] carried had increased to 280 ... these were completely expended during the very first weeks of war." 86 Stig Förster wrote that the German general staff never received funds to prepare for a drawn-out campaign. All the general staff could do was "to concentrate

80. Graydon A. Tunstall, "Austria-Hungary," in Hamilton and Herwig, The Origins of World War I, pp. 145-146; David Stevenson, The First World War and International Politics (Oxford: Oxford University Press, 1988), p. 17; and Stevenson, Armaments and the Coming of War, p. 369.

81. William Jannen Jr., The Lions of July: Prelude to War, 1914 (Novato, Calif.: Presidio, 1996), p. 164.

82. Tunstall, "Austria-Hungary," p. 146.

83. Lieber, "The New History of World War I and What It Means for International Relations Theory," p. 182.

84. Quoted in ibid., p. 182.

85. Martin van Creveld, Supplying War: Logistics from Wallenstein to Patton (Cambridge: Cambridge University Press, 2004), p. 110; Tuchman, The Guns of August, p. 119; Van Evera, Causes of War, p. 26; and Farrar, "The Short War Illusion," p. 41.

86. Van Creveld, Supplying War, p. 110. 
on its own immediate concern: planning for the campaign of the first couple of weeks in a war." 87

\section{THE ENTENTE}

The Entente followed the same pattern as the Central Powers. Overconfidence in Russia, France, and Britain rose as war became perceived as imminent, which translated into a greater willingness to fight and an attraction to ambitious war plans.

HYPOTHESIS 1: IMPLEMENTAL MIND-SETS AND INCREASING OVERCONFIDENCE. Russian leaders displayed more overconfidence about the outcome of war as conflict drew close. From 1908 to the summer of 1914, while war remained hypothetical, there was an "unwritten but generally accepted conception of Austria-Hungary as beatable and Germany as well-nigh unbeatable." ${ }^{\prime 8}$

In July 1914, however, the Russian civilian and military leadership's mindset shifted significantly. Policy in July 1914 "rested on assumptions that war was possible without domestic breakdown, and that it could be waged with a reasonable prospect of success." 89 As Niall Ferguson put it, "The Russians overestimated their own military capability almost as much as the Germans did; they also stubbornly ignored the evidence that their political system would crack under the strain of another war so soon after the fiasco of defeat by Japan in 1905." 90 Russian military officers thought that after the first few battles, the multinational Austro-Hungarian army would disintegrate. ${ }^{91}$ War Minister Gen. Vladimir Soukhomlinov foresaw victory in a few months, an assessment shared by most of the Russian ministers. ${ }^{92}$ A common estimation was that Russian troops would be in Berlin within six weeks: "[P]essimists who suggested six months were considered defeatists." 93

French confidence also grew when war appeared imminent in mid-to-late

87. Stig Förster, "Dreams and Nightmares: German Military Leadership and the Images of Future Warfare, 1871-1914," in Manfred F. Boemeke, Roger Chickering, and Förster, eds., Anticipating Total War: The German and American Experiences, 1871-1914 (Washington, D.C.: German Historical Institute, 1999), p. 372, quoted in Snyder, “Correspondence: Defensive Realism and the 'New' History of World War I," pp. 178-179.

88. William C. Fuller, "The Russian Empire," in Ernest R. May, ed., Knowing One's Enemies: Intelligence Assessment before the Two World Wars (Princeton, N.J.: Princeton University Press, 1984), p. 111.

89. Stevenson, The First World War and International Politics, p. 32; and David G. Herrmann, The Arming of Europe and the Making of the First World War (Princeton, N.J.: Princeton University Press, 1996), p. 210.

90. Niall Ferguson, Empire: The Rise and Demise of the British World Order and the Lessons for Global Power (New York: Basic Books, 2004), p. 249.

91. Van Evera, Causes of War, p. 205.

92. Ibid., p. 39.

93. Tuchman, The Guns of August, p. 119. 
July 1914. Before the July crisis, when war was not yet certain, Chief of Staff Joseph Joffre predicted that a future conflict would prove a long struggle. Napoleon had famously asserted that he fought only when he estimated he had a 70 percent chance of winning. During the second Moroccan crisis in 1911, Joffre was asked if France had a 70 percent of winning against Germany: Joffre said no. ${ }^{94}$ As Eugenia Kiesling put it, "[Joffre] had provided warnings of French weakness to discourage his government from an avoidable war." 95 French caution was even transparent enough for German observers to notice: "Both the [German] ambassador and military attaché in Paris wrote repeatedly to Berlin throughout the period between 1912 and 1914 that any temptation in France to underestimate German strength was overridden by an acute consciousness of French weakness at home and abroad." 96

Everything changed, however, when conflict approached. On July 24, France's war minister, Adolphe Messimy, told Joffre of the possibility that France would have to fight. Joffre recalled that "[t]he long habit of constantly thinking of what must be done in case war broke out caused me to regard this redoubtable eventuality without any surprise, so I very quietly answered: 'Well, Monsieur le Ministre, if we have to make war, we will do so.' It may be that my attitude brought some comfort to M. Messimy, for he came over to me, pressed my hand with some emotion, crying out 'Bravo!' We then set to work in the calmest fashion imaginable to examine the first measures that must be taken if the menace of war became more certain." 97 Once Joffre concluded that war was imminent, he confidently predicted victory. ${ }^{98}$ The Russian embassy in Paris reported the mood among French military circles at the end of July as "very elated," with "unconcealed joy at exploiting the . . favorable strategic situation." 99 Joffre's role was especially important in the July crisis, because President Raymond Poincaré and Premier René Viviani were both away visiting St. Petersburg during the critical days of July 16-29. This meant that "[t]he key decision maker in Paris was General Joseph Joffre." ${ }^{100}$ French civilian lead-

94. Christopher M. Andrew, "France and the German Menace," in May, Knowing One's Enemies, p. 146.

95. Eugenia C. Kiesling, "France," in Hamilton and Herwig, The Origins of World War I, p. 252.

96. Hewitson, Germany and the Causes of the First World War, p. 179.

97. Quoted in Dong Sun Lee, Power Shifts, Strategy, and War: Declining States and International Conflict (New York: Routledge, 2008), p. 70. This statement implies that French actors were not yet 100 percent certain that war would occur, but they evidently believed that war was more likely than before, and moved toward implemental rather than deliberative activities, which would be associated with the formation of implemental mind-sets.

98. Farrar, "The Short War Illusion," p. 43.

99. Stevenson, Armaments and the Coming of War, p. 388.

100. Samuel R. Williamson Jr. and Ernest R. May, “An Identity of Opinion: Historians and July 1914," Journal of Modern History, Vol. 79, No. 2 (June 2007), pp. 335-387, at p. 347. 
ers also believed there were good prospects for victory. ${ }^{101}$ Indeed, the French went to war "more confident of victory than they had been since the FrancoPrussian War."102

Relative to the other great powers, British perceptions that war was imminent were delayed because Britain committed to war late. And as the Rubicon theory would predict, there was also a delay in the increase of British confidence. In the week before August 2, French and Russian leaders displayed overconfidence while British leaders were still wary. During this time, London looked in horror at the gathering war clouds across the continent. Foreign Secretary Sir Edward Grey was torn between his belief that war would be short and a "deep-seated fear that it would prove a terrible catastrophe."103 The Liberal Party Prime Minister H.H. Asquith wrote on July 24 that "we are within measurable, or imaginable, distance of a real Armageddon."104 But this disaster would befall the other great powers, not Britain. Asquith commented: "Happily there seems to be no reason why we should be anything more than spectators."105 The prime minister estimated as late as August 2 that threequarters of his own party in Parliament wanted to remain neutral. First Lord of the Admiralty Winston Churchill felt that three-quarters of the cabinet also opposed war. ${ }^{106}$ In what appears to be a classic deliberative mind-set, the British government assessed the options with considerable caution. ${ }^{107}$

London decided to fight very late in the crisis, between August 2 and August 4. During this period, there is considerable evidence of a shift from a deliberative mind-set to an implemental mind-set, with an associated boost in overconfidence. When war drew near, British officials began to see the war in a more positive manner as the cabinet and Parliament rallied around the war effort. Antiwar sentiment drained away and confidence surged. Grey told the House of Commons on August 4, "[I]f we engaged in war, we shall suffer but little more than we shall suffer even if we stand aside." 108 As Geoffrey Blainey noted, "[M] ost ministers also expected a short war." ${ }^{109}$ Sir James Grierson, director of military operations, thought Germany would be "easy prey" for

101. Stevenson, The First World War and International Politics, pp. 33-34.

102. Andrew, "France and the German Menace," p. 145.

103. Quoted in Zara S. Steiner and Keith Neilson, Britain and the Origins of the First World War (New York: Palgrave Macmillan, 2003), p. 256.

104. Quoted in James Joll, The Origins of the First World War (New York: Longman, 1984), p. 113.

105. Quoted in Steiner and Neilson, Britain and the Origins of the First World War, pp. 236-237.

106. Ibid., pp. 238, 248-256; and J. Paul Harris, "Great Britain," in Hamilton and Herwig, Decisions for War, pp. 288-289.

107. Cameron Hazlehurst, Politicians at War, July 1914 to May 1915: A Prologue to the Triumph of Lloyd George (London: Jonathan Cape, 1971), chap. 8.

108. Quoted in Steiner and Neilson, Britain and the Origins of the First World War, pp. 223-234.

109. Blainey, The Causes of War, p. 37. 
Britain and France. ${ }^{110}$ Robert Jervis summed up the changing patterns of expectations: "The doubts of British Liberals about whether to go to war in 1914 were almost totally dissolved after the decision was reached."111

The United States also displayed the predicted shift in confidence as actors switched from deliberative to implemental mind-sets. As expected, American officials did not exhibit a dramatic change in confidence during the 1914 July crisis, because U.S. involvement in war was not imminent. As late as 1917, Woodrow Wilson was skeptical about the wisdom of joining the fray: "[I]t would be a crime for this Government to involve itself in the war to such an extent as to make it impossible to save Europe afterward."112 U.S. entry might destroy Germany and produce a "dictated peace, a victorious peace" rather than a just settlement. Meanwhile, on the home front, the war effort could spur dangerous militarism that would threaten the fabric of American democracy. ${ }^{113}$

Wilson's beliefs, however, changed in the first week of April, as he crossed the Rubicon and took the United States into the war. According to Robert Tucker, "His excessive pessimism over the undesirable consequences of war was soon transformed into an excessive optimism over what war might accomplish."114 Jervis identified the same phenomenon: "[O]nly slowly and painfully did Woodrow Wilson decide to ask for a declaration of war against Germany. His awareness of the costs of entering the war was acute. But after the decision was made, he became certain that his policy was the only wise and proper one."115

HYPOTHESIS 2: OVERCONFIDENCE AND THE OUTBREAK OF WAR. Implemental mind-sets may explain an important puzzle about the Russian and French role in the outbreak of World War I. If Germany and Austria-Hungary were confident that the time was right to fight, why did Russia and France not try more seriously to delay war? As Marc Trachtenberg puts it, "Germany's 'window of opportunity' was the Entente's 'window of vulnerability,' and although Germany had an extra incentive to act, Russia and France had an extra

110. Quoted in Van Evera, Causes of War, p. 20.

111. Jervis, Perception and Misperception in International Politics, p. 384.

112. Quoted in Kendrick A. Clements, Woodrow Wilson: World Statesman (Boston: Twayne, 1987), p. 167.

113. Ross A. Kennedy, The Will to Believe: Woodrow Wilson, World War I, and America's Strategy for Peace and Security (Kent, Ohio: Kent State University Press, 2009), pp. 128-129; and Jan Willem Schulte Nordholt, Woodrow Wilson: A Life for World Peace, trans. Herbert H. Rowen (Berkeley: University of California Press, 1991), pp. 216-217.

114. Robert W. Tucker, Woodrow Wilson and the Great War: Reconsidering America's Neutrality 19141917 (Charlottesville: University of Virginia Press, 2007), p. 203.

115. Jervis, Perception and Misperception in International Politics, p. 389. 
incentive to be cautious and put off the conflict if they could."116 Trachtenberg suggests that the answer lies in the "astonishing irrationality" of the Russian leadership. ${ }^{117}$ But this only begs the question: Why were the Russians so irrational, especially at such a critical juncture?

The Rubicon theory of war suggests an answer. In 1914 the leadership in Paris and St. Petersburg did not seek war. At the same time, however, they feared that the Entente would fall apart if they did not make a united stand. And crucially, they became increasingly confident of victory even if war arose. ${ }^{118}$ As Dong Sun Lee noted, “To Berlin's surprise, St. Petersburg calmly accepted the seemingly unavoidable war rather than back down as it had done in the previous crises. . . Given [his] expressions of military confidence, [Russian Foreign Minister Sergei] Sazonov did not hesitate to stand firmly behind the Serbs even at the risk of war with the Central Powers."119 Implemental mind-sets decreased the odds that France and Russia would pay any price for peace.

HYPOTHESIS 3: OVERCONFIDENCE AND RISKY WAR PLANS. Implemental mindsets may also have shaped Entente war plans during July 1914. In the years before 1914, many Russian war plans had an air of caution or even pessimism. They assumed that Sweden and Romania would support Germany and Austria-Hungary; some officials also added China and Japan to the list of likely adversaries. ${ }^{120}$ But in the wake of the July crisis, war planning became much more sanguine. Few Russians argued for long-term mobilization. Instead, Russian armies would rely on limited stockpiles of weapons, ammunition, and supplies. ${ }^{121}$ Moreover, Russia settled on "an extremely ambitious strategy" that involved a simultaneous three-pronged assault on Germany and Austria. ${ }^{122}$

Overconfidence may also have influenced French strategic planning. In July 1914 the French maintained full confidence in their aggressive Plan XVII, which envisaged an immediate assault into Alsace-Lorraine. Joffre rejected warnings that Germany would thwart his strategy by attacking through Belgium. Kiesling writes, "Although Joffre had acknowledged Germany's ability to invade Belgium in January 1912, he appears to have forgotten the whole

116. Marc Trachtenberg, History and Strategy (Princeton,. N.J.: Princeton University Press, 1991), p. 70 .

117. Ibid., p. 70 .

118. Herrmann, The Arming of Europe and the Making of the First World War, p. 218.

119. Lee, Power Shifts, Strategy, and War, p. 68.

120. Fuller, "The Russian Empire," p. 110.

121. Ibid.

122. Van Evera, Causes of War, p. 196. 
issue two years later."123 As Jan Tanenbaum put it, "[Joffre] believed that an all-out immediate offensive, one that was oblivious to the enemy's intentions, location, and firepower, was the best strategy to pursue."124 Samuel Williamson and Ernest May concluded that Joffre "and most of his colleagues disregarded any information at odds with their assumptions. Though some intelligence indicated that Germany might use reserve troops and thus be able to make a sweep above the River Meuse, Joffre paid no attention. He had just committed himself to Plan XVII, and he did not want to reconsider its premises." ${ }^{125}$ Like the Germans, the French also made "no preparations for a longer struggle" - revealing that confidence in a short and successful war was genuine and not just rhetorical. ${ }^{126}$

British war planning was also based on illusory assumptions. The British general staff "underrated many of the physical and technical aspects of modern warfare. Not only did they fail to appreciate the German capacity to crush fortified redoubts with the enormous Krupp and Skoda siege guns, but they also had not realized the value of machine guns." ${ }^{127}$ Disastrously, therefore, the prevailing view was that "mind would prevail over matter; morale would triumph over machine guns." ${ }^{128}$ Decisionmakers believed that Britain could fight at arm's length using naval and colonial strength, along with a small professional army. Military leaders misread the strategic situation in a "naive belief that only a limited amount of support would be necessary"-because Russia would crush Germany from the east. ${ }^{129}$

\section{Conclusion}

When people perceive war as imminent, they cross a psychological Rubicon. Implemental mind-sets and a surge in confidence increase the attraction of risky war plans, and may heighten the probability of the outbreak of war.

The predictions of the Rubicon theory of war were mainly supported in the case of World War I. In contrast to the common claim of blanket overconfidence on all sides prior to war, we found that confidence varied systematically. Overconfidence was initially suppressed and then grew as war drew near (with some important qualifications, particularly for German perceptions).

123. Kiesling, “France," pp. 255-256.

124. Jan Karl Tanenbaum, "French Estimates of Germany's Operational War Plans," in May, Knowing One's Enemies, pp. 150-171, at p. 171.

125. Williamson and May, "An Identity of Opinion," p. 347.

126. Farrar, "The Short War Illusion," p. 43.

127. Paul M. Kennedy, “Great Britain before 1914," in May, Knowing One's Enemies, p. 192.

128. Van Evera, Causes of War, p. 197.

129. Kennedy, “Great Britain before 1914," p. 194. 
This helps to explain why the issue of confidence has been so controversial in the literature on World War I: scholars can find instances of pessimism or optimism by looking at different stages of the crisis. The increase in overconfidence on the eve of war is especially striking given that three of the five great powers that initially entered the war-Austria-Hungary, France, and Russiahad lost their last major conflict. All three countries believed that on this occasion the outcome would be very different.

Depending on the historiographical school about the origins of World War I to which one subscribes, implemental mind-sets may have directly contributed to the outbreak of the war, by amplifying the perceived benefits and downplaying the perceived costs of fighting. Decisionmakers also became less inclined to pull back from the brink. Meanwhile, overconfidence increased risk taking in war planning. Decisionmakers were resistant to revising their plans even when the changing strategic environment undermined the assumptions behind those plans. And when war plans were revised, they tended to become more ambitious and even reckless.

The hypothesis that policymakers in 1914 assessed the decisions for war as rational actors is violated in two ways. First, despite the availability of reasonable information about relative capabilities, all sides were overconfident on the eve of war, as demonstrated by their expectations, their military strategies, and their failure to plan for a long war. Second, the confidence of all sides increased over time as war approached-with no obvious rational explanation.

The Rubicon theory of war suggests three major avenues for further research. First, scholars could examine other types of cases, such as crises that do not end in war, to explain how conflict is avoided despite the possible emergence of implemental mind-sets and associated overconfidence. Second, wargame experiments could test the effects of implemental mind-sets and overconfidence in a controlled laboratory setting using simulated international crises. Third, the Rubicon theory can be applied to many other domains of international and domestic politics, where actors shift from deliberation to implementation, from trade policy to congressional bargaining.

In one sense, the adoption of implemental mind-sets on the eve of war may be advantageous for decisionmakers. Implemental mind-sets can help actors strive harder, ignore distractions, persist in the face of adversity, and achieve difficult tasks. ${ }^{130}$ As Carl von Clausewitz wrote, "Boldness in war . . . must be granted a certain power over and above successful calculations involving

130. Peter M. Gollwitzer and Paschal Sheeran, "Implementation Intentions and Goal Achievement: A Meta-Analysis of Effects and Processes," Advances in Experimental Social Psychology, Vol. 38 (2006), pp. 69-119. 
space, time, and magnitude of forces, for wherever it is superior, it will take advantage of its opponents' weakness."131

There is, however, a fine line between boldness and excessive risk taking. Implemental mind-sets may lead to dangerous overconfidence, increasing the probability of wars against superior opponents and reckless military planning. As each actor in 1914 determined that war was imminent-starting with Austria-Hungary and ending with Britain-its confidence in victory spiked, and its behavior became more assertive and less reflective.

We offer several policy implications based on our findings. First, decisionmakers must be self-aware. The sudden rush of confidence as war approaches may be exhilarating, but it could also be a dangerous delusion. Policymakers should predict in advance the occurrence of this dynamic and be prepared to fight against it. Second, leaders must consider the adversary's perspective. If a rival state sees war as imminent, it is likely to grow in confidence about the chances of victory, potentially dragging both sides into war. Thus, brinkmanship is even more dangerous than previously thought. Third, leaders should plan for conflict ahead of time, before entering the danger zone of implemental mind-sets where overconfident biases contaminate the decisionmaking process. Would the Iraq War have proved quite so costly if the United States had enacted OPLAN 1003-98-Gen. Anthony Zinni's 1999 plan for the invasion of Iraq with 400,000 troops?

131. Carl von Clausewitz, On War, ed. and trans., Michael Howard and Peter Paret (Princeton, N.J.: Princeton University Press, 1976/1832), p. 190. 